\title{
低床式アンダーフロア空調システ THE AIR FLOW DISTRIBUTION IN A 厶の二重床内気流分布に関する研 PRESSURE PLENUM CHAMBER OF 究 \\ THE UNDER FLOOR AIR \\ CONDITIONING SYSTEM WITH LOW RISE RAISED FLOOR SYSTEM
}

\section{Hisashi HANZAWA}

Masaaki HIGUCHI

It is significant for the under floor air conditioning systems with a low rise raised floor that distributions of air flow and static pressure in a pressure plenum chamber are maintained properly. Majer problems about the introducing supply air to the pressure plenum chamber and the effect of obstacles to the air flow distribution in the chamber were found. Technical solutions to avoid these problems are suggested. Guide vanes are effective to make introducing air flow distribution properly. Less than one second height of the chamber has no influence to the air flow distribution.

キーワード :

床吹出し空調, 二重床, 気流分布, 静圧分布, 空調システム

Keywords :

Under floor air conditioning, Raised floor, Air flow distribution, Static pressure distribution

\section{1 はじめに}

近年のオフィスビルでは、低床型 O A フロアが普及してきている。 二重床内を加圧チャンバとして利用するアンダーフロア空調システ ムを導入する際に、O A フロアの高さを増加させるのは階高の増加 を招き、建設コストが増大することになる。従って、低床型 O A フ ロアによる二重床スペースをそのまま給気用加圧チャンバとして利 用する必要が生じる。しかし有効高さが低い二重床を給気チャンバ として利用する場合、二重床内の風速の増加あるいは圧力損失の増 加によって、二重床内の静圧及び吹出し風量に不均一が生じること が予測される。また、二重床内の温度及び吹出し温度にばらつきが 生じることも予測される。それらにより、室内の温熱環境が悪化す る可能性がある。従って、低床型 OAフロアによる二重床内気流分 布に関する問題点を明らかにし、対策を講じることが重要である。

筆者らは $1 / 5$ 縮尺模型を用いて、二重床内の気流性状(風向・風速、 二重床内静圧)に関する実験を行い、その問題点について検討した。 1)（1991）また、二重床高さ60m（有効床高さ $34 \mathrm{~mm}$ ）の実大オフィス における二重床内の気流性状を測定し、二重床高さ $60 \mathrm{~mm}$ の床吹出し

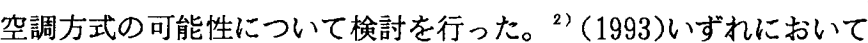
も、空調機から二重床内への給気導入方法ならびに二重床内の障害 物による気流分布の検討を行った。なお気流場が予測できれば、温 度分布の予測は可能であるという観点から今回は温度場に関ずる検 討は行っていない。本報では、これらの模型実験ならびに実大オフ イスにおける実測により得られた、低床型OAフロアによる二重床 内気流性状の特徴、問題点及びその対応策について述べる。

なおこれまでに二重床高さ $300 \mathrm{~mm}$ （有効）を対象とした $1 / 10$ 縮尺 模型実験 ${ }^{3)}$ (1992)、二重床高さ250m（有効）を対象とした $1 / 2$ 縮尺 模型実験 ${ }^{4)}$ (1992)、二重床高さ75、150mm（有効）を対象とした $1 / 5$
縮尺模型実験 ${ }^{5}$ 6) ${ }^{6}$ (1994)、二重床高さ 70、100、150、300m対象 とした縮尺模型実験 ${ }^{\prime}$ (1994)が報告されている。また、気流シミュ レーションでの簡易予測法に関する検討7（1994）も報告されている。

\section{2 樎尺模型実験による二重床内気流性状の把握}

二重床の高さ、二重床内への空気導入口の大きさ、障害物の有無 の影響を検討するためそれらをパラメータとして、縮尺 $1 / 5$ の模型 を用い、二重床内の風向・風速、静圧分布を測定した。また、給気 導入口直後に設置するガイドベーンの効果についても検討した。

\section{1 実倹做要}

図.1に実験装置の概要を示す。対象空間として $15 \mathrm{~m} \times 15 \mathrm{~m}$ の平面 を想定した二重床内模型 $(3 \mathrm{~m} \times 3 \mathrm{~m}$ 、縮尺 $1 / 5)$ とした。実際の吹出口 と有効開口面積が等価である、直径 $20 \mathrm{~mm}$ 単純開口を吹出口として、 52 個配置した。二重床内風速を無指向性風速計で、二重床内静圧亡 実験室内との差圧を沈鐘式微差圧計で測定した。

表.1に実験条件を示す。対象とした二重床高さは実大で $300 \mathrm{~m}$ と $120 \mathrm{mr}$ である。吹出口 1 個当りの風量は実物て $100 \mathrm{~m}^{3} / \mathrm{h}$ 亡なるように 設定し、風速の縮率を1：1として等温実験を行った。印の実験条 件については床下の障害物(ケーブル、ダクト等)の影響を確認する 実験、及び空気導入口直後にガイドベーンを設置し気流の均等拡散 を図った実験を行った。障害物、ガイドベーンの位置は図.1に示す。

\section{2 実験結果亡考察}

\section{2.1 給気導入口臤置}

給気導入方法による二重床内風向・風速分布を図.2.1（1)全面導 入、(2) 1 所導入) に、1 1 所導入時の二重床内静圧分布を図. 2.2 に示す。全面導入時には気流はチャンバ奥に平行流で直進し二重床 内静圧もほぼ一定であった。これに対して 1 ヶ所導入では大きな洞

\footnotetext{
*1 (株) 竹中工務店技術研究所応用研究開発部 主任研究員

(T270-13 千葉県印西市大塚1-5-1)

*2 (株) 竹中工務吉技術研究所応用研究開発部 研究員・工博
}

*1 Chier Researcher, TAKENAKA CORPORATION, Research \& Development Institute

*2 Researcher, TAKENAKA CORPORATION, Research \& Development Institute, Dr. Eng. 

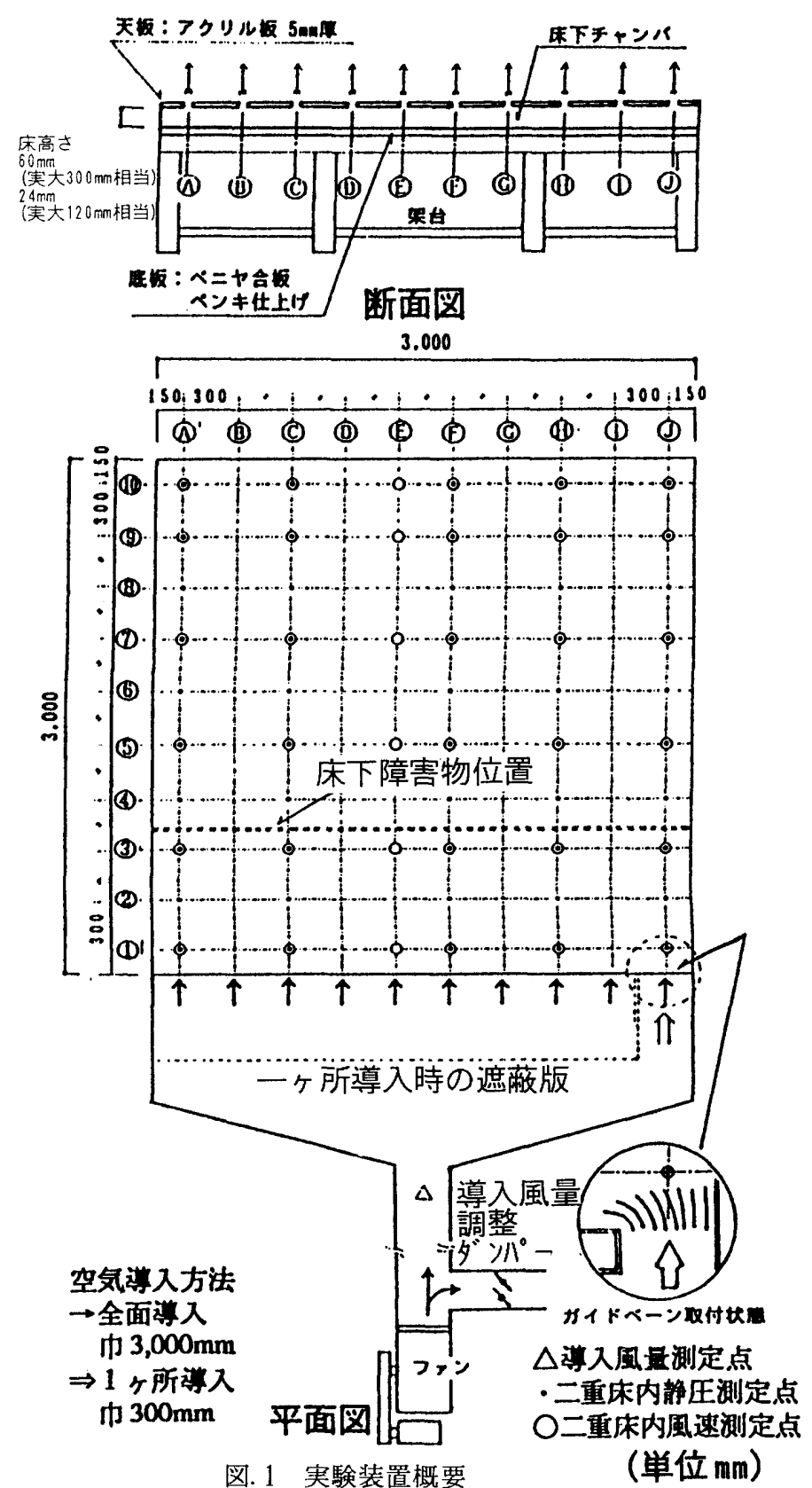

表. 1 実験条件一覧(縮尺模型実験)

\begin{tabular}{|c|c|c|}
\hline 床高さ(mm) & \multicolumn{2}{|c|}{ 空気導入方法 } \\
\hline ［］は模型床高さ & 全面導入 & 1 ヶ所導入 \\
\hline $300[60]$ & 0 & $\mathrm{O}$ \\
\hline $120[24]$ & 0 & (a) \\
\hline
\end{tabular}

ができ、渦の中心部付近で空気が滞留する傾向がある。二重床内静 圧は、空気の流れに沿って值が変化し、導入口からの空気が最初に 壁面に衝突する付近で高く、渦の中心部で低い。また隅角部では大 きな渦と逆方向の小さな渦が生じており、静圧が低かった。

全面導入時には、低床(二重床高さ $120 \mathrm{~mm}$ )でも二重床内静圧の分 布に大きなばらつきはなかったが、1ヶ所導入の場合は二重床内静 圧にばらつきが生じている。（図.2.2）また、導入した空気が渦の 中心部に達するまでの経路が長く（図. 2.1）、途中での熱損失によ り冷房時に吹出空気温度が高くなる可能性がある。従ってチャンバ 全体に均一に気流を送る土夫が必要である。

\section{2.2 床高さの影留}

1 ヶ所導入の場合の二重床高さによる影響を二重床内静压の出現 頻度分布によって示す。（図.3(1)二重床高さ300m、(2)同 $120 \mathrm{~mm})$ ) 高さ $120 \mathrm{~mm}$ の二重床内静圧は $0.9 \sim 1.5 \mathrm{mmAq}$ と高さ $300 \mathrm{~mm}$ の結果と比較 してばらつきが大きく、標準偏差も約 5 倍となっている。

二重床高さが低い亡、導入風量が等しい場合二重床内の風速が大 きくなり、摩擦による圧力損失が大きくなる。これによって二重床 内静压のばらつきが大きくなると考えられる。導入風速を大きくし すぎないことで、二重床内静圧のばらつきを小さくできるといえる。

\section{2. 3 障害物の影響}

図.4に導入気流方向に直行して二重床高さを閉塞する障害物を設 置した場合の二重床内風向・風速の分布（1１/2閉塞、(2) $3 / 4$ 閉塞） を示す。 $1 / 2$ 閉塞時には、導入口からの気流は中心方に曲げられ る傾向はあるが、障害物を乗り越え大きな一つの渦を形成しており、 障害物がない場合と同様の流れ性状を示す。 $3 / 4$ 閉塞時には障害物 に到達した気流はそのまま障害物に沿って流れ、障害物前後で二つ の渦を形成している。3/4閉塞時の二重床内静圧分布は、導入空気 が障害物とぶつかる部分で高く、障害物の手前側の渦の中心付近で 低くなる。ただし、障害物以降の静圧のばらつきは小さい。（図.5）

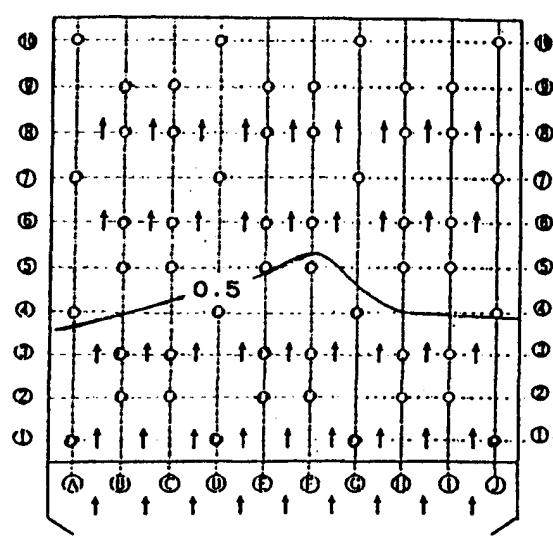

(1)全面道入

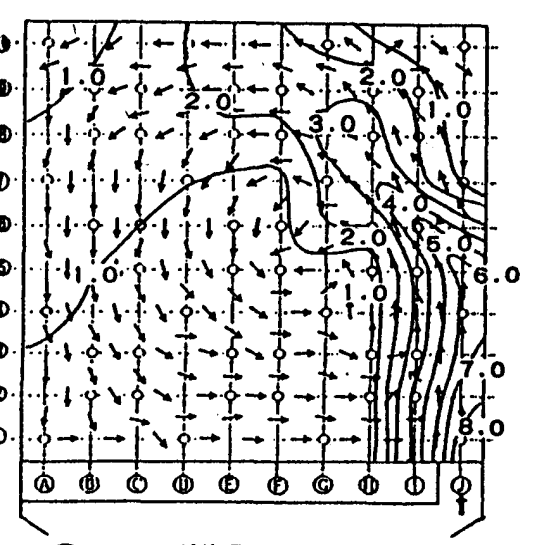

(2) 1 个所道入 (単位m/s)

図. 2.1 二重床内風向・風速分布（床高さ $120 \mathrm{~mm}$ ） O : 床吹出し口

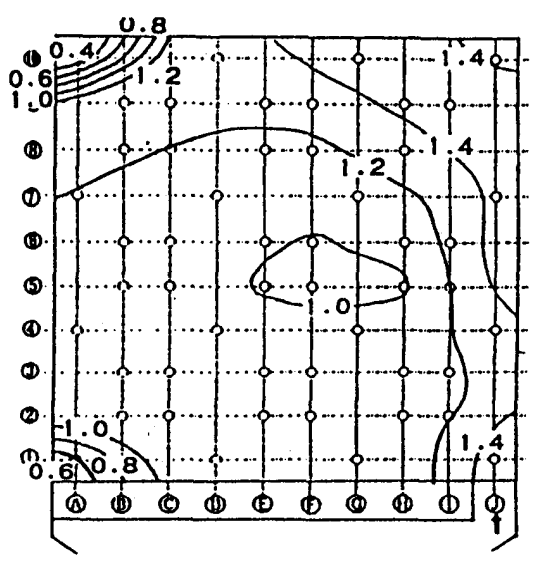

$\mathrm{O}$ : 床吹出し口（単位mmAq）

図. 2.2 二重床内静压分布（床高さ $120 \mathrm{~mm} 、 1$ ヶ所導入） 


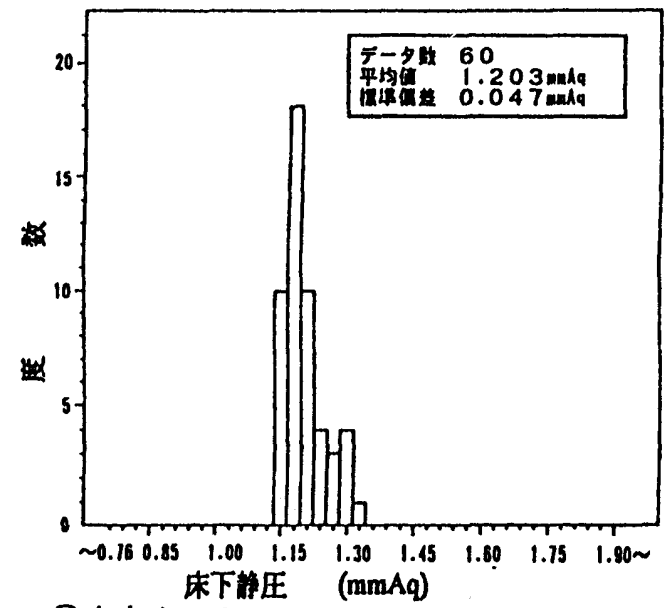

(1)床高さ300mn

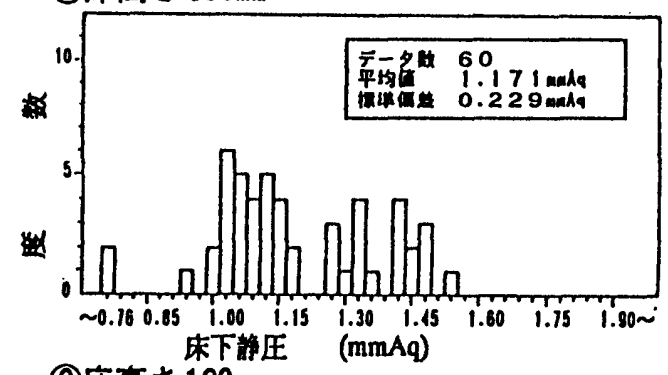

(2)床高さ $120 \mathrm{mn}$

図. 3 二重床内静圧出現頻度分布（1ヶ所導入）

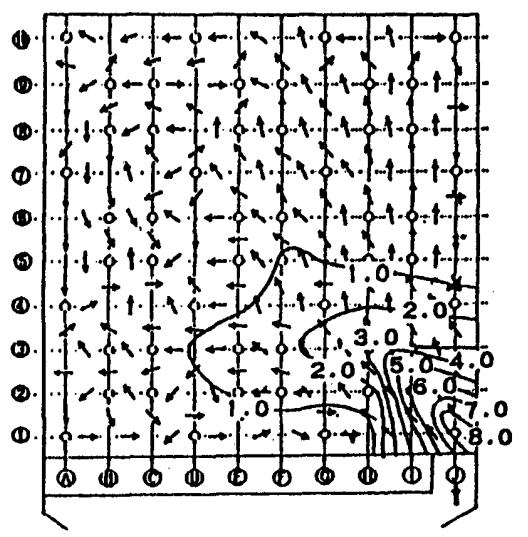

\section{0 : 床吹出しロ (単位 $\mathrm{m} / \mathrm{s}$ )}

図.6 二重床内風向・風速分布 (床高さ $120 \mathrm{~mm} 、 1$ ヶ所導入、 ガイドベーン有り)

\section{2.4 ガイドベーンの効果}

1 ケ所導入で導入口直後にガイドベーンを設置した場合の二重床 内風向・風速の分布を図.6に示す。ガイドベーンにより導入空気仙 放射状に拡がり、ガイドベーン無しの 1 ヶ所導入(図.2 (2))でみら れた気流の滞留は消え、チャンバ内の各点に最短経路で空気が流れ ている。これによってチャンバ内での熱損失による床吹出し空気温 度の上昇は少なくなると考兄られる。ガイドベーン設置の場合の二 重床内静圧の頻度分布を図.7に示す。1 r所導入時(図. 3 (2) $)$ と比 較すると床下静圧のばらつきは小さく、ガイドベーンによって床吹 出し風量のばらつきを抑えることができるといえる。

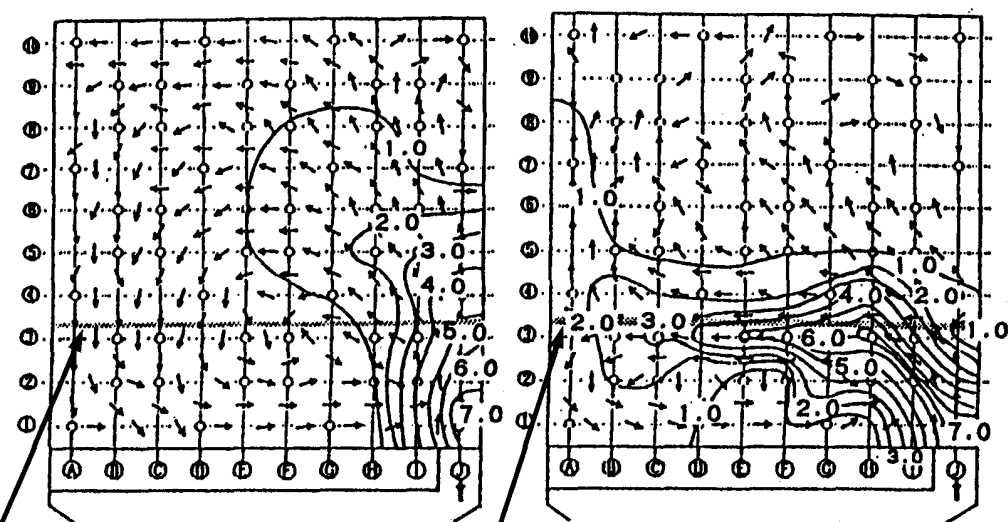

(1)障害物 $1 / 2$ 閉塞障害物 (2)障害物 $3 / 4$ 閉勧（位 $\mathrm{m} / \mathrm{s}$ )

$O:$ 床吹出し口

図. 4 二重床内風向・風速分布（床高さ $120 \mathrm{~mm} 、 1$ ヶ所導入）

障害物

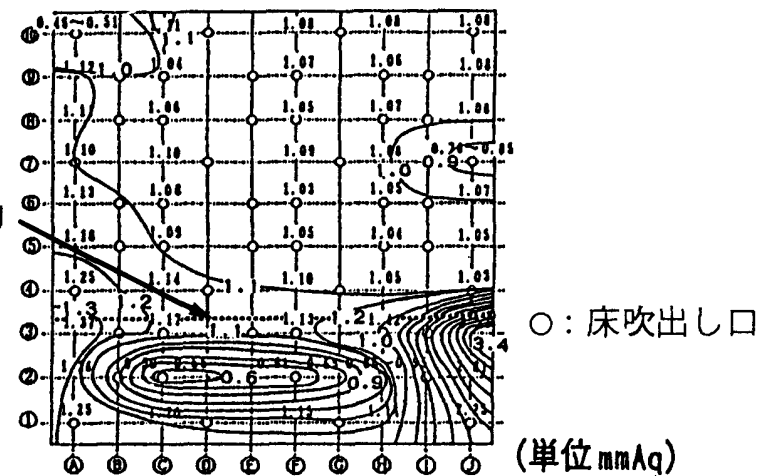

图. 5 二重床内静圧分布（床高さ $120 \mathrm{~mm} 、 1$ ヶ所導入、障害物 $3 / 4$ 閉塞）

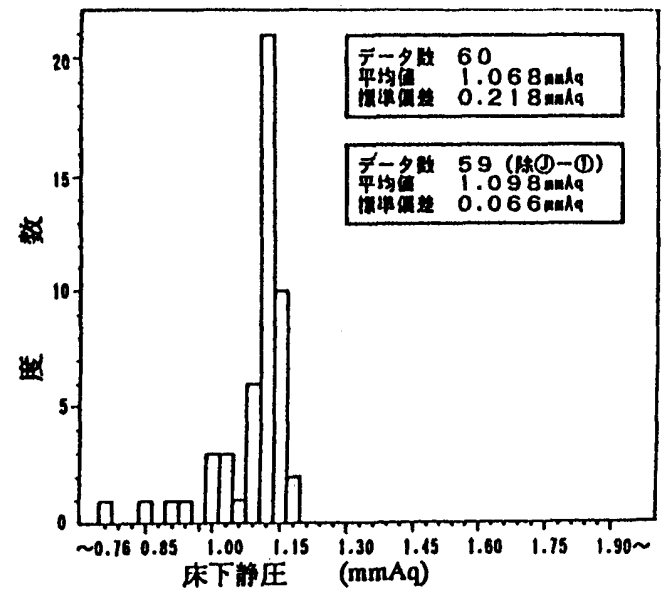

図.7 二重床内静压出現頻度分布（床高さ $120 \mathrm{~mm} 、 1 ヶ$ 所導入、 ガイドベーン有り)

\section{3 実大オフィスにおける二重床内気流性状の把握}

実大のオフィスにおいて二重床高さ60m(有効床高さ $34 \mathrm{~mm}$ )のO A フロアを利用した床吹出し空調方式について、二重床内の気流性状 を把握する実験を行った。

\section{1 実跧枚要}

実験対象亡したオフィスの平面図 $(38 \mathrm{~m} \times 38 \mathrm{~m})$ を図. 8 に示す。 図中 $\square$ の領域の二重床内を区画し、加圧方式のアンダーフロ ア空調を実施した。図.9に空調空気導入ダクト近傍の断面詳細図を 示す。二重床内への空調空気の導入は条件によって、2ヶ所の繸夕゙ クト $(200 \times 500 \mathrm{~mm}) 、$ しくは 1 ヶ所の綐ダクト $(500 \times 500 \mathrm{~mm})$ を通じ 


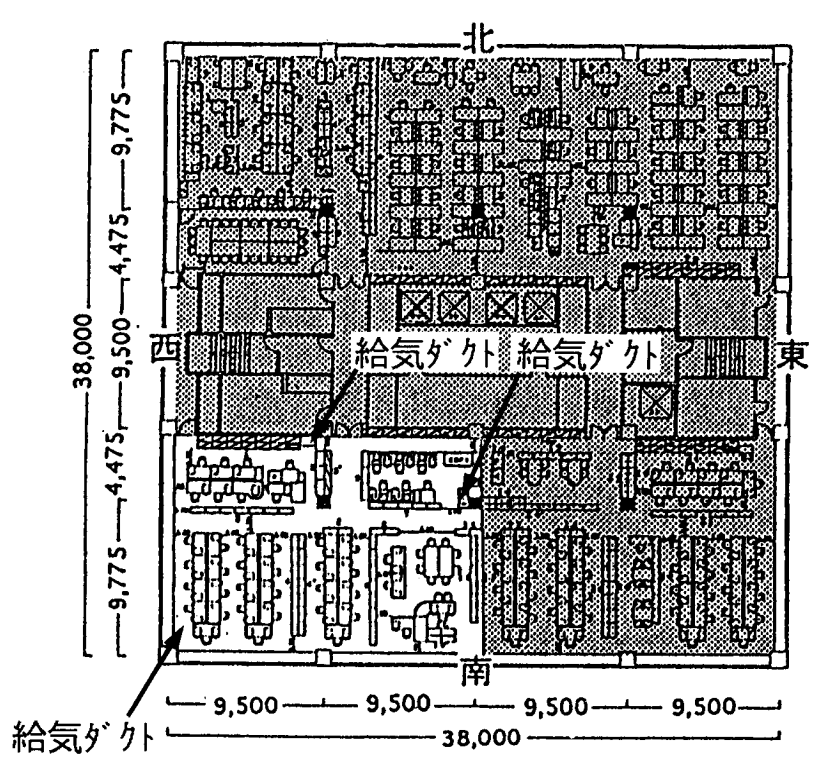

図. 8 実験対象オフィス平面図 (単位 $\mathrm{mm}$ )

て行った。床吹出しロは1個あたり風量 $100 \mathrm{~m}^{3} / \mathrm{h}$ 旋回流型吹出しロ を34個設置し、最大風量に設定した。二重床内風速を無指向性風速 計で、二重床内静圧とオフィス空間との差圧を沈鐘式の微差圧計で 測定した。表.2に実験条件を示す。導入口配置、二重床内の障害物 (ケーブルの幹線等) の量をパラメータとした条件について実験を

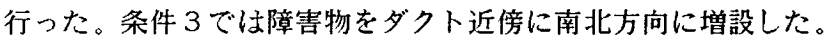

\section{2 結果と考繁}

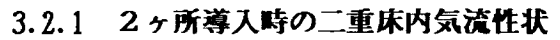

図. 10に条件 1 の二重床内風向・風速分布、図.11に二重床内静圧 分布を示す。二重床内風速は導入ダクト近傍で最も大きく、南側空 面に向かって減衰している。2つのダクトから二重床内に吹出した 空気は放射状に拡がり、床内で衝突したのち、南側空面に向かって 流れていると考えられる。西側ダクト近傍にはOAケーブルが集中

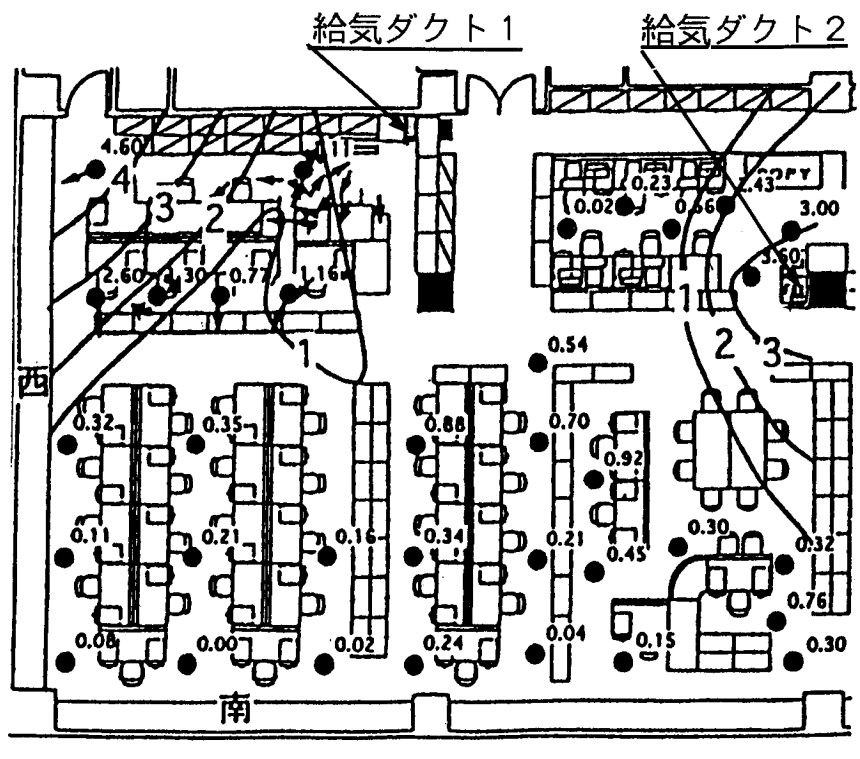

: 床吹出しロ (単位 $m / s)$
表. 2 実験条件一覧(実大オフィス実験)

\begin{tabular}{c|c|c}
\hline 条件 & 空気導入口配置 & 二重床内障害物 \\
\hline 1 & 2 ヶ所 (コア側) & 通常使用状態 \\
\hline 2 & 1 ヶ所 (南西空側) & 通常使用状態 \\
\hline 3 & 1 ヶ所 (南西空側) & Fヶーブル15本追加 \\
\hline
\end{tabular}

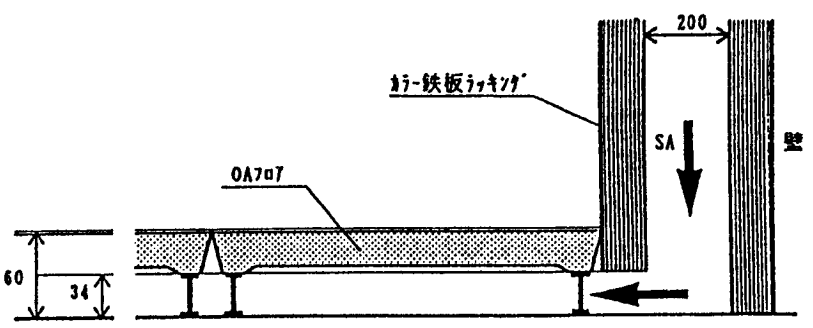

図.9 S A ダクト近辺断面図（単位mm）

しているため、一部流れが滞留しているが、二重床内の気流は比較 的スムーズに流れているといえる。

二重床内静压については導入夕゙クト近傍で高くなっっているが、 全体としては $1 \mathrm{~mm} \mathrm{Aq}$ 以下とほぼ均一である。静圧の值から、導入夕゙ クト近傍の床吹出し風量が 3 割程度多く、今回用いた床吹出しロの 静圧損失と風量は両対数軸で（静圧損失）の $2 \mathrm{x}$ (風量) で表わせ る。従って静圧のばらつきが 2 割以内なので、床吹出し風量は 1 割 以内の差であると推定される。

二重床内の導入口は 2 ケ所しかないが、ダクトから下向きに空気 を導入しているため、放射状に空気が拡がり、二重床内風速が速く 減衰する。これにより、高静圧の領域が少なくなっていると考えら れ二重床内へ横向きに空気を導入するよりも、静圧分布の点で有利 であるとえいる。ただし、二重床内への空気導入時の圧力損失は增 加し、空調機のファン動力が増加する。

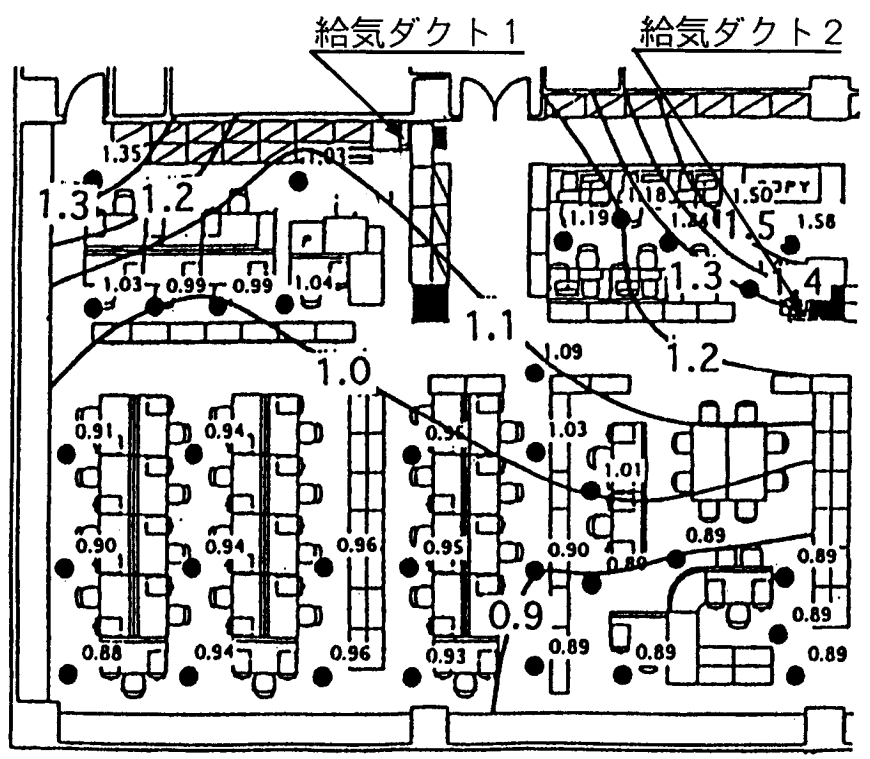

• : 床吹出しロ (単位 $m m A q)$

図.11 二重床内静压分布（条件 1 ） 


\section{2 .2 導入口目冝の影琯}

図.12に条件 20 二重床内風向・風速分布、図.13に二重床内静圧 分布を示す。導入口近傍の風速は韵 $15 \mathrm{~m}$ と速く、導入口から気流が 放射状に拡散している。高風速域は南側、西側空面に沿って拡がり、 尊入口からおよそ $10 \mathrm{~m}$ の距離まで風速 $2 \mathrm{~m} / \mathrm{s}$ 以上の領域が拡がってい る。

二重床内静圧は尊入口近傍で最も高く $3.5 \mathrm{mmAq}$ 越える。導入口 と対角の位置の静圧は最も低く、約 $1 \mathrm{mmAq}$ とっている。床吹出し 風量には約 2 倍の差が生じると推定される。また、高静圧の領域は 南側空面に沿って拡がっており、室中央付近以降は層状に静压が低

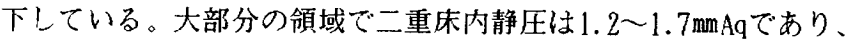
床吹出し口特性より風量に約 2 割のばらつきが生じると推定される。

\section{2 .3 二重床内障害物の量の影䇾}

図.14に条件 3 の二重床内風向・風速分布を示す。図.15に二重床
内静圧分布を示す。導入口からの気流は最初放射状に拡散するが、 障害物が南北方向に設置されてるために、高風速域が南側空面に沿 って拡がらず、室中央に向かう傾向がある。導入口からの気流は障 害物以降では障害物のある位置から全面尊入されたような気流分布 を示している。二重床内の風速が $2 \mathrm{~m} / \mathrm{s}$ 以下の領域は障害物が無いと きに比べると小さい。

二重床内静圧は導入口近傍で最も高く $4.5 \mathrm{mmAq}$ を越え、導入口と 対角の位置で最も低く約 $1 \mathrm{mmAq}$ となっている。障害物が無いときと 同様、吹出し風量に約 2 倍の差が生じると推定される。障害物があ るため、高静圧の領域は南側空面に沿って拡がらず、障害物以降で 層状に静圧が低下する。障害物より導入口の静圧は高くなるが、障

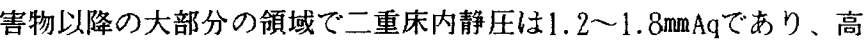
静圧の領域が小さくなる。障害物が無いときと同様、床吹出し口特 性より、風量に約 2 割のばらつきが生じるとが推定される。

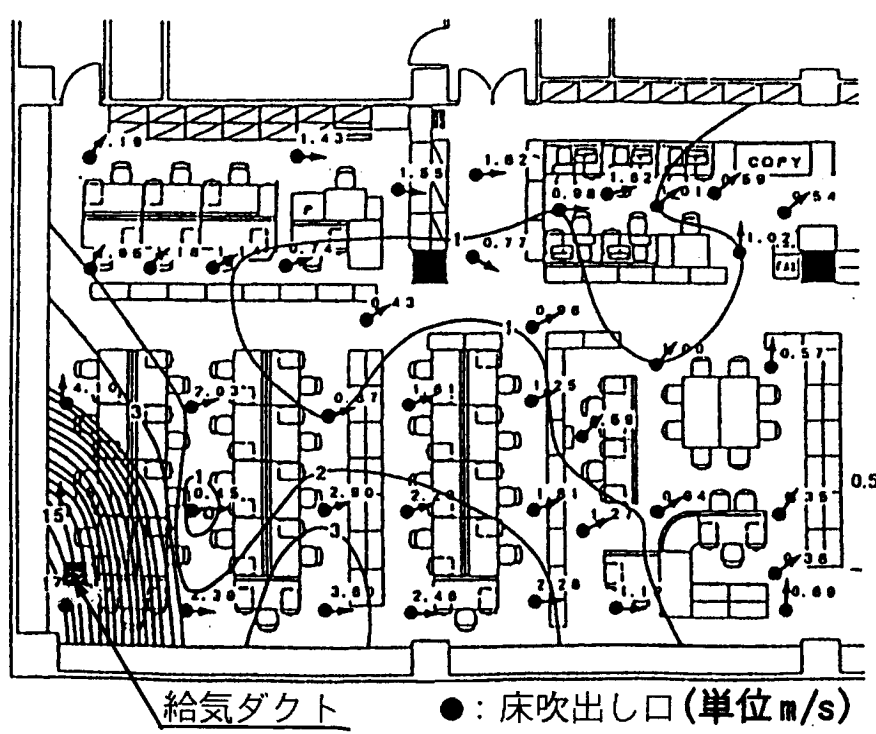

図. 12 二重床内風速・風向分布（条件 2)

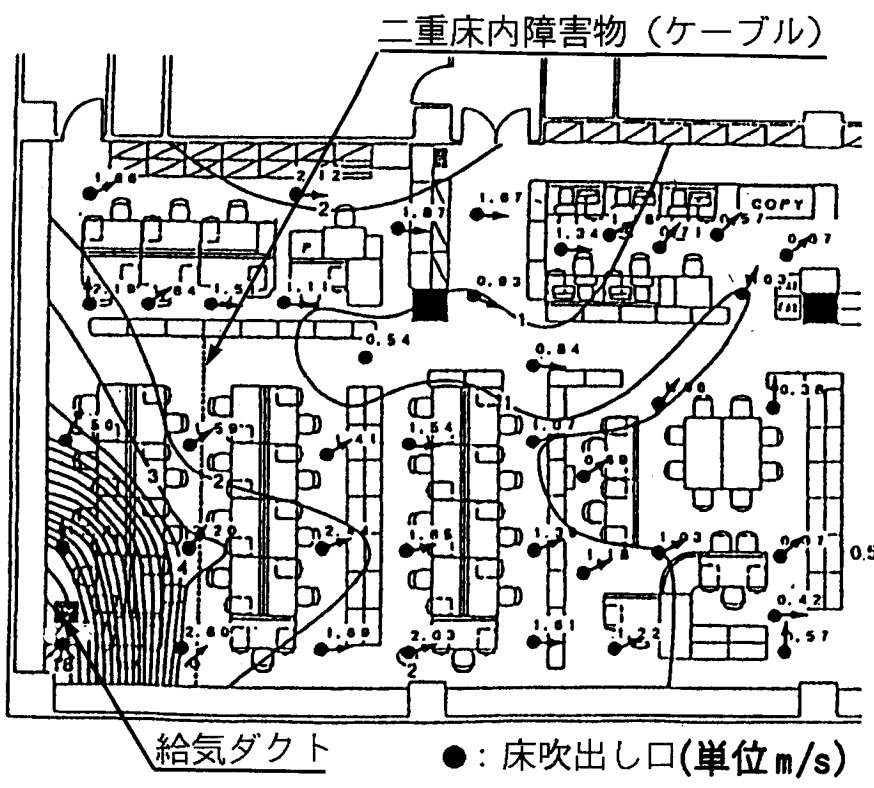

図. 14 二重床内風速・風向分布（条件 3 ）

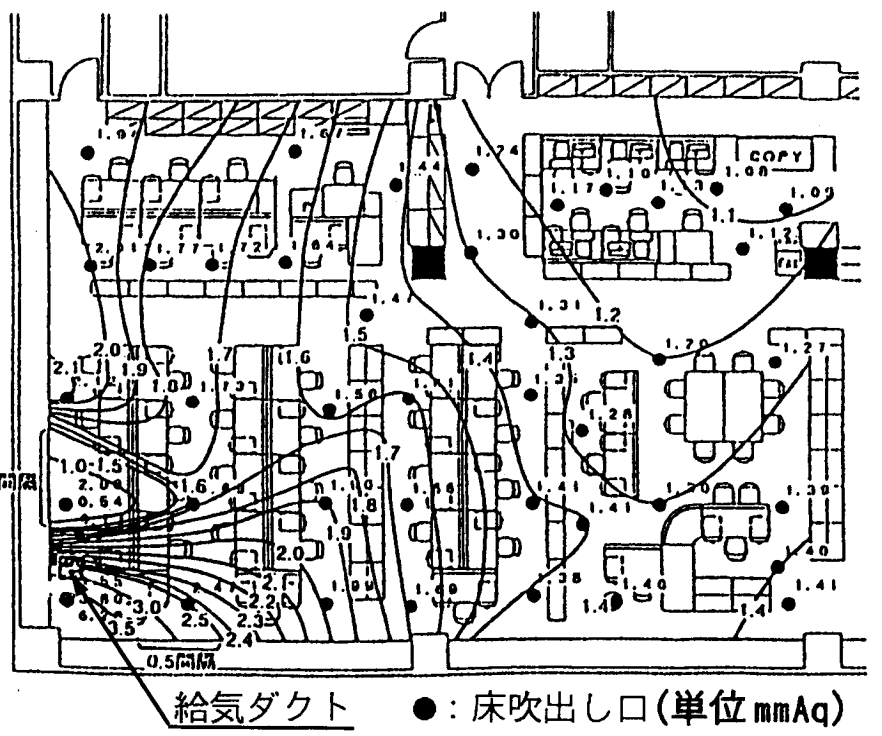

図.13 二重床内静圧分布 (条件 2)

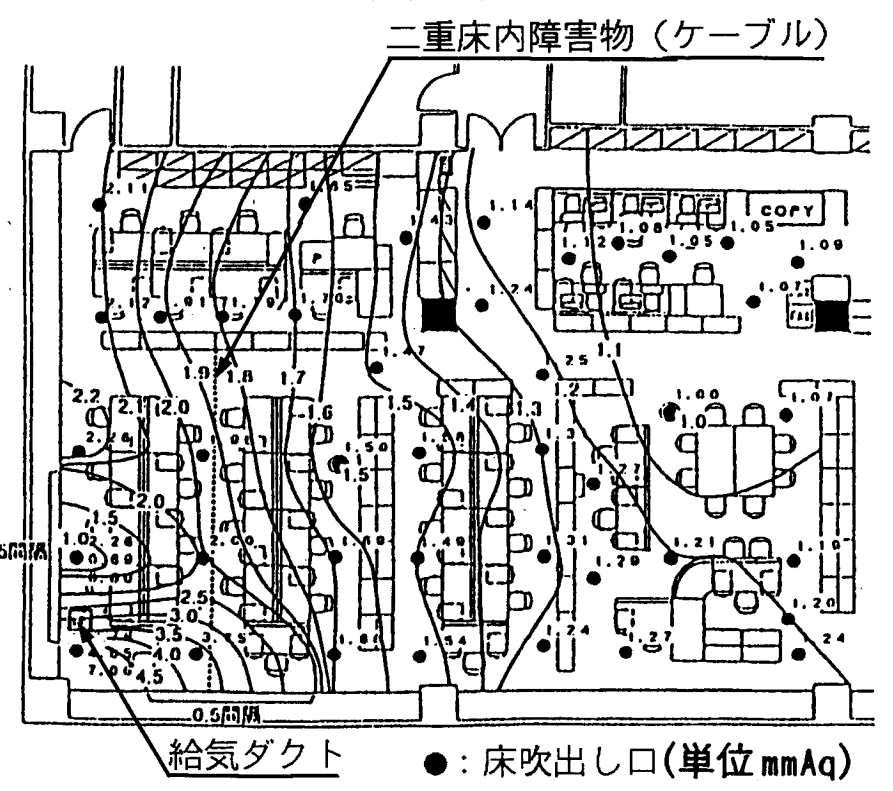

図.15 二重床内静压分布（条件 3 ） 


\section{4 おわりに}

アンダーフロア空調システムの普及によって、より低床の○Aフ ロアへの適用が求められている。加圧チャンバータイプのアンダー フロアー空調の場合は、二重床内の静压分布が均一であれば、各床 吹出し口からの吹出し風量が均等に維持される。また、二重床内の 気流分布が均等であれば、床吹出し温度がほぼ均一になる。したが つて、低床型OAフロアを用いた場合の二重床内の気流分布特性を 把握しておくことは、床吹出し風量を適正に維持し、室内環境を良 好に保つために重要である。今回、縮尺模型を用いた実験結果によ って以下のことを確認した。

(1)空調機から二重床内への空気が 1 所から導入されると、二重床 内静圧のばらつきが大きくなる。また、導入空気の到達に時間の かかる床吹出しロがある。

(2)全面導入時には二重床内静圧の分布はより均等になる。

(3) 1 ケ所導入の場合は導入口直後へのガイドベーンの設置により、

二重床内静圧分布は改善される。

(4)二重床内の障害物は床下断面が $3 / 4$ 以上閉塞されると、風速分布 が大きく変化し、二重床内静圧のばらつきが大きくなる。但し、 障害物以降の静圧のばらつきは小さくなる。

また、二重床有効高さ34mmの赛大オフィスでの実験により、以下 のことが明らかになった。

(1)二重床内へ 2 所から導入した場合は、二重床内静圧のばらつき は比較的小さかった。導入口からの気流が二重床内で放射状に拡 散する方式のため、二重床内の風速が適正となったためである。 (2)二重床内へ 1 所から導入した場合は、二重床内の風速が速く、

二重床内静圧のばらつきも大きかった。

(3)障害物部分での圧力損失が大きいため、障害物以降の領域では、 障害物位置から全面導入されたような気流分布を示し、障害物以 降の静压のばらつきは比較的小さかった。

二重床への空気導入方法によって、低床型OAフロアによる加圧
チャンバー方式のアンダーフロア空調が可能であることを確認した。 ただし、低床のOAフロア等を利用する場合、二重床内への導入口 1 ヶ所の受忛持ち面積が大きすぎると、二重床内静圧のばらつきが 大きくなり床吹出し風量がばらつくことになる。二重床高さと空調 対象面積を設定したときに、二重床内の障害物を標準的に設定して、 二重床内の風速分布、静圧分布の予測モデルを構築しその静圧分布 が1割以内のばらつきに収まるような、床下への導入口の設置個数 すなわち 1 所の導入口の受け持ち面積を決定できる可能性がある。

今後は、二重床内の気流分布特性を簡易に予測できる計算モデル を構築し、設計時に十分な㛟討ができる手法を確立する必要がある。

\section{参考文献}

1）桶口, 長沢, 半澤, 森山, 有吉, 鹿倉, 荒川 : 低床式アンダーフロア空調の二重 床内気流性状, 空気調和衛生工学会学術講演会講演論文集, pp. 209-212, 1991年

2) 桶口, 長沢, 半澤, 小林, 品田, 貴田 : 低床式アンダーフロア空調の二重床内 気流性状一OA フロア利用の実大オフィスにおける実験一, 空気調和衛生 工学会学術講演会講演論文集, pp. 453-456, 1993年

3）竹浪, 栗林, 山崎 : 床吹出し空調方式に関する研究（その2）床下均圧チャ ンバ方式の检討, 空気調和衛生工学会学術講演会論文集, pp. 277-280, 1992年

4) 梁尾, 梅主, 小池, 大黒 : 床吹出空調の評価研究（その1）床下障害物の影 響と床面の漏気量, 空気調和衛生工学会学術講演会講演論文集, pp. 293296,1992 年

5) 大和瀬, 中谷, 高橋, 竹村：加圧方式の床吹出し空調システムに関する研究 （その 2) 模型による吹出し気流分布の実験的検証, 空気調和衛生工学会 学術講演会講演論文集, pp. 1713-1716，1994年

6) 中谷, 大和瀬, 高橋, 竹村：加圧方式の床吹出し空調システムに関する研究 （その 3) 気流拡散板の効果之林下障害物の影響, 空気調和衛生工学会学 術講演会講演論文集, pp. 1717-1720，1994年

7) 倉㴊, 相原, 谷川：CF D手法を用いた床吹出し空調システムの最適化に関 する研究 一模型実験及び数值シミュレーション手法の概要一, pp. 17371740,1994 年

[1996 年 5 月 23 日原稿受理 1996 年 9 月 10 日採用決定 $]$ 